\title{
Communication Source, Brand Image and Brand Choices of Postgraduate Students
}

\author{
Indra Devi Subramaniam ${ }^{1}$, Wan Fadzilah Wan Yusof $\mathrm{f}^{1} \&$ Noor Shahaliza Othman ${ }^{1}$ \\ ${ }^{1}$ Graduate School of Management, Multimedia University, Cyberjaya, Malaysia \\ Correspondence: Indra Devi Subramaniam, Graduate School of Management, Multimedia University, Cyberjaya, \\ Malaysia. Tel: 603-8312-5718. E-mail: indra@mmu.edu.my
}

Received: October 8, 2014

Accepted: October 29, $2014 \quad$ Online Published: November 22, 2014

doi:10.5539/ijbm.v9n12p94

URL: http://dx.doi.org/10.5539/ijbm.v9n12p94

\begin{abstract}
The purpose of this study is to determine post graduate students' perception of the communication sources, brand image of the university and their brand choices when selecting a university to pursue their graduate studies. A quantitative research approach in the form of a correlation study was used in this research. This study was conducted in a corporate university of the national telecommunication company in Malaysia. The respondents were post graduate students pursuing master the business management (MBA) program. A total of 41 students constituted the sample. A structured questionnaire was used to collect data. University web site was found to have the greatest reach and influence on students' decision to study in the university. Published ranking was second and friends /family was third. Of the top ten sources having the greatest reach and influence, six were university sources. Quality / reputation of the faculty topped the list on important decision criteria for selecting to study in the university. This was followed by prestige /global recognition of the university; published ranking of its graduate management programme and that it was an accredited program. Accredited programme, quality and reputation of the faculty, global recognition and prestige of the school were among the top reasons given by graduating MBA students for selecting the school. The study was confined to one institution only. Therefore the results are only generalizable to the population from that university. Further research should include samples from other universities so that the results can be generalizable over a larger population. The paper contributes to marketing research for institutions of higher education. The finding could be used to develop effective marketing strategy.
\end{abstract}

Keywords: brand image, brand choices, postgraduate students, Corporate University, Malaysia

\section{Introduction}

\subsection{Background of the Study}

There is intense competition among providers of higher education all over the world. This is also true for many business schools offering post graduate programmes. Many of these schools are facing problem of reduced student enrollment. In countries like the USA, enrollment into programmes like the MBA has not followed the economic situation. In fact it has been countercyclical. When economy was bad, workers who were unemployed who were not engaged in other activities joined business schools to pursue MBA. At the same time employed workers pursued part-time degrees to remain competitive in the workplace. Due to this, enrollment in MBA programmes did not fall during bad economic times. All this has changed. There appears to be a slump in enrollment to business schools.

According to Dailey, Anderson, Duffy, Krimm and Thomas (2006), there was a drop of roughly 30 percent between 1998 and 2006; some seeing declines in excess of 50 percent in applications to Business Week's Top MBA programmes. The 2012 report by the Graduate Management Admission Council (GMAC), the organization that administers the test many business schools use to assess applicants' qualifications for admissions indicates that less than half of each MBA program type reported increased volume over 2011, 45 percent of all MBA programs saw declines and 10 percent reported no change. Even the growth in application volume was due to gains in online/distance learning programmes According to Briggs (2013), while economic situation, lifestyle and shift in culture could be likely reasons for enrollment, but business schools themselves should accept some of the blame for the fall in enrollment. He states that business schools have brought this situation on themselves because of ineffective marketing and branding programmes. 
Business schools should employ effective marketing practices when promoting programs. They need to create marketing messages by starting with the fundamental question, "what are the factors that students consider when determining whether and where to pursue the postgraduate degree?" This information is essential if business school wish to attract more students. The decreasing number of student enrollment shows that marketing messages and campaigns that may have worked for years no longer do. There is overabundance of competition among public and private institutions. Many of these competitors have large marketing budgets. So business schools are faced with competitors that have advertising campaigns at national levels, large budgets for marketing and more local staff recruiters. In addition many business schools that are profit motivated often have less stringent entry requirements. Because of these challenges, business schools must determine what matters to the target audience in order to develop effective strategic communications messages to attract new students and hold on to or even increase their market share as well as to tailor programmes that students desire. Universities have to make marketing decisions such as what strategies they should use based on empirical evidence if they want to able to compete with other institutions of higher learning.

While corporate leaders understand the need for empirical data for decision-making, higher education have for a long time paid little attention to the need to generate data for management decision making (Michael, 2001). According to Mark (2002) many business schools have been marketing specific graduate school programmes without the assistance of empirical research. A possible reason could be limited acceptance of marketing concept by graduate schools (Nicholls et al., 1995). However this situation is changing. Many universities are now appointing marketing personnel to focus on the customer to develop marketing programmes. The goal is to attract sufficient number of students with desired attributes in the programmes offered by the universities. To achieve this goal, the marketing initiatives must focus on matching the attributes and benefits of the programme with the customer needs, the customer in this case being the prospective student (Mark, 2002).

Communication strategies have to be developed based on the needs of the students. In order to do this, universities need to conduct a customer analysis. Marketing programmes that are based on customer analysis are more likely to be successful in attracting students.

\subsection{Statement of the Problem}

Student enrollment is the bread and butter of all university programmes. Fall in student enrollment could affect the income to the university and sustainability of the programmes offered by the respective schools and could in extreme condition threaten the survival of the school. Therefore a fall in student enrollment is a cause for concern. The university under study is a corporate university that has previously enjoyed a good reputation for post graduate programmes offered by its business school. However, in the past one year it has been experiencing a drastic fall in enrollment. The reason for this has been attributed to aggressive marketing by competitors with big budget for advertising, lower entry qualification and less challenging programme. However no empirical study has been conducted to determine the students' perception of the communication sources, brand image of the university, the reasons why they choose this university and the general criteria students would use to select a university to pursue their post graduate business programme. This study aims to address this gap.

\subsection{Research Questions}

The following are the research questions for this study:

1). Which among the different communication sources were the most effective in influencing the students' decision to study in the university?

2). What is the extent of the students' familiarity with the university brand?

$3)$. What features of the university and its program were important in students' decision to study in the university?

\subsection{Significance of the Study}

The results of this study would enable the marketing personnel of the university to develop appropriate strategic marketing strategies to attract students to the university. It would also enable the university to identify weaknesses in the current strategies and to address them.

\section{Literature Review}

There is a lot of controversy on the marketing of higher education according to Heslop and Nadeau (2010). There appears to be a lack of consensus on what should be the focal pint of marketing higher education especially for MBA programs. Some focus on hallmarks and elements of programs and process-related characteristics, others on the program inputs and immediate, short-term, intermediate, and long-term outcomes. Some emphasized the importance of specific program features and benefits. Ivy and Naude (2010) and Dailey et al. (2010) state that there 
is not enough information on how higher education should be marketed and that it is an important but little understood area. In a survey conducted by GMAC $®$ on prospective MBA students, it was found that there were extended time lapses between the times the students think about studying for MBA to the time they finally graduate. There are three stages in this process where the students have to make decisions. The first decision is whether an MBA is right for them. Having decided to pursue an MBA degree, they then have to make decisions regarding the brand of the school that they will study which will answer the question where they should pursue their study that is what attributes should the school that they wish to study have and the final decision is about actually committing to study. Carrel and Schoenbachler (2001), who examined the factors that students considered when making decisions to study in an Executive MBA program, found that the most important decision factor for students was the need for new knowledge, followed closely by the convenience and flexible scheduling of classes. This suggests that students are interested in programmes that will enhance their job performance while not interfering with their schedule of work.

Heslop and Nadeau (2010) surveyed prospective students who attended MBA fair on the decision considerations when wishing to study for MBA. They found that important decision considerations were financial cost, investment of time, career uncertainty, future job opportunity, and an expressed interest in learning. Heslop and Nadeau (2010), solicited information on critical factors influencing applicants selecting a particular school in which to study. Reputation, quality of both the faculty and the university as a whole, location convenience, personal fit of program style or goals, scheduling and programmatic flexibility, cost, and the ability to gain entry into the program were found to be important decision considerations.

Schoenfeld \& Bruce (2005), conducted a study on factors that influence students' decision to select a school or university to pursue their postgraduate education. They studied the communication sources, brand image of the university, characteristics of the University of their Choice or the programmes offered by the university and the importance the students place on certain characteristics of business schools in general. According to Schoenfeld \& Bruce (2005), there are three sources of communication that can influence this choice. They are university source, personal sources and media sources.

The Global MBA Survey conducted in 2005 found that the communication source that had the greatest reach were from the school. Top of the list was the school's Web site. The next was personally corresponding with the school source. Other school sources that had great influence were interaction with admission / MBA programme personnel. Two of the sources were from the media namely published ranking of the school and MBA related Web sites.

According to Schoenfeld \& Bruce (2005), since three of the four communication sources that have the greatest reach to students intending to study for MBA were from the university, universities should increase their effort and initiatives to improve these sources especially the university Web sites and personal communication from schools so that they are always current, updated and informative.

When the influence and reach of the communication sources were compared using standardized scores, the results showed that published ranking of the school was the most influential communication source. Other sources in order of importance were school Web site, interaction with school admission/ MBA programme personnel, personal school correspondence, friends and relatives, MBA related web sites, current students, peers, online business magazines, and MBA related books / publications.

Survey conducted in the 2002-2004 Global MBA ${ }^{\circledR}$ Graduate Survey, graduating MBA students were asked to rank the criteria they had used in selecting their school. The results showed that that the fact that it was an accredited programme topped the list. This was followed in order of importance, by quality and reputation of the faculty, global recognition and prestige of the school, location of the school, the type of career options that were available to its graduates, ranking of its graduate programmes, whether the school offered the specific curriculum the students were looking for, to what extent the school was able to place its graduates in suitable jobs and the fact the school had students and faculties from diverse background and experience.

When asked to rate the importance they placed on the different criteria when selecting business schools in general, quality and reputation of the school was ranked first. This was followed by specific aspects of the program, costs, curriculum, career prospects and profile of students in the class (mba.com Registrants survey conducted in October 2004). When standardized scores were used to make comparisons, again quality of the faculty topped the list. This was followed by local respect and reputation, rigor of the programme and quality of the current students. Type of programme was ranked third. Published ranking ranked sixth. 


\section{Methodology}

The study setting is the corporate university of the national telecommunication company. The study was prompted by the need to determine the university's brand image among potential students. With increasing number of institutions offering post graduate programs in Malaysia, this university is facing intense competition and a fall in the number of student enrollment. To improve its brand visibility and image, the university uses several different communication sources to reach out to both local and international students. Among these are university web site, current students, interaction with admission//post graduate programme personnel, university alumni, internet, admission interviews, post graduate fairs and reception/open day. Understanding the criteria the students' use to select the university and the business school will further enable the university to meet the students' needs and could help in attracting more students.

A quantitative research approach is used in this study. A cross-sectional field study research design is used. The population is new students who have enrolled in the university's graduate business programmes. A total of 41 students formed the sample. This was the total number of students who had enrolled in the first semester of the post graduate program. Of these forty were enrolled in the MBA program and 1 was enrolled in the DBA program. Essentially this is a census study.

The research instrument is a structured questionnaire. It consists of five sections. Section A solicited information regarding the demography of the respondents. Section B requested information regarding the communication source that had the greatest reach and influence on the students' decision to select the university. Section C requested information regarding the brand image of the university. Section D requested information on the criteria used by students to make decision to study in the university. Section E requested information on the criteria students used to select a graduate business school. Summary statistics in the form of frequency and percentage was used to answer research questions 1 to 4 . Independent $t$ test was used to answer research question 5. Pearson product moment correlation was used to answer research questions 6 and 7.

\section{Results}

\subsection{Demography of the Respondents}

The demography of the respondents is presented in Table 1. Majority (95.2\%) of the respondents were between 20 to 30 years of age. There were more male respondents $(63.6 \%)$ compared to female respondents $(36.6 \%)$. The sample consisted of both Malaysian (51.2\%) and non-Malaysian (41.8\%). A large portion of the sample were unemployed $(36.6 \%)$ or fresh graduates $(24.4 \%)$, while $31.7 \%$ were employed full time. Only a small portion (3.7\%) was employed part time. The respondents had pursued different undergraduate field of study; $46.34 \%$ had majored in Business Administration, 43.90\% in Engineering, 7.32\% in IT while the remaining 2.44 had studied accounting. Various reasons were cited for wanting to pursue post graduate studies.

Table 1. Demography of respondents

\begin{tabular}{lll}
\hline Demography & Frequency & Percentage \\
\hline Age & 22 & 53.7 \\
$20-25$ years & 17 & 41.5 \\
$26-30$ years & 1 & 2.4 \\
$31-40$ years & 1 & 2.4 \\
$>40$ years & & \\
& & \\
Sex & 26 & 63.4 \\
Male & 15 & 36.6 \\
Female & & \\
Nationality & & \\
Malaysia & 20 & 41.8 \\
Non-Malaysian & 21 & 51.2 \\
& & \\
Employment Status & & 31.7 \\
Employed full time & 13 & 7.3 \\
Employed part time & 3 & 36.6 \\
Unemployed & 15 & \\
\hline
\end{tabular}




\begin{tabular}{lll}
\hline Fresh Graduate & 10 & 24.4 \\
Undergraduate Field of Study & & \\
Engineering & 18 & 43.90 \\
Accounting & 1 & 2.44 \\
Business Administration & 19 & 46.34 \\
IT & 3 & 7.32 \\
& & \\
Reason for pursuing postgraduate studies & & \\
Better job prospects & 13 & 31.7 \\
Better pay & 1 & 2.4 \\
Increased promotion opportunities & 16 & 39.0 \\
Change in interest & 3 & 7.3 \\
Personal Satisfaction & 5 & 12.2 \\
All my friends have post graduate degrees & 2 & 4.9 \\
Intend to continue to PhD & 1 & 2.4 \\
& & \\
Programs & & 78.0 \\
MBA Full time & 32 & 22.0 \\
MBA Part time & 9 & \\
\hline
\end{tabular}

Increased promotion opportunities topped the list with $39 \%$ of the respondents citing it as a reason for pursuing postgraduate studies. Other reasons are better job prospects (31.7\%), personal satisfaction (12.2\%), change of interest (7.3\%), all my friends have post graduate degrees (4.9\%), better pay (2.4\%), and intend to study for $\mathrm{PhD}$ (2.4\%). Most of them were full time students (78\%) while the remaining $22 \%$ were enrolled as part-time students.

\subsection{Communication Sources with Greatest Reach and Influenced Students'Decision to Study in the University}

Tables $2 \mathrm{a}, 2 \mathrm{~b}$ and $2 \mathrm{c}$ present the communication sources that had greatest reach and influenced students to study in the university.

Table 2a. University sources

\begin{tabular}{|c|c|c|c|c|}
\hline \multirow[t]{2}{*}{ No. } & \multirow[b]{2}{*}{ University Communication Source } & \multicolumn{3}{|c|}{ Had Greatest Reach and Influenced Decision to Study at the University } \\
\hline & & $\begin{array}{l}\text { A Great Deal or Good } \\
\text { Amount }\end{array}$ & Neutral & A Little or None at All \\
\hline 1. & University Web Site & 87.8 & 0.0 & 12.2 \\
\hline 2. & Current students & 51.2 & 34.1 & 14.7 \\
\hline 3. & $\begin{array}{l}\text { Interaction with admission//post graduate } \\
\text { programme personnel }\end{array}$ & 48.8 & 36.6 & 14.6 \\
\hline 4. & Previous experience with university & 46.3 & 34.1 & 19.6 \\
\hline 5. & University Alumni & 43.9 & 41.5 & 14.6 \\
\hline 6. & Personal correspondence with university & 43.9 & 46.3 & 9.8 \\
\hline 7. & Internet & 31.7 & 31.7 & 36.6 \\
\hline 8. & Admission interview & 29.3 & 46.3 & 24.4 \\
\hline 9. & Post Graduate Fairs & 29.3 & 46.3 & 24.4 \\
\hline 10. & Reception/Open Day & 19.5 & 48.8 & 31.7 \\
\hline
\end{tabular}

Table 2a presents the reach and influence of university sources in descending order. University Web site (87.8\%) had the greatest reach and influence on students' decision to study at the university. This was followed by current students $(51.2 \%)$, interaction with admission /post graduate programme personnel (48.8\%), previous experience with university $(46.3 \%)$, university alumni $\left(43.9^{\wedge}\right)$, and personal correspondence with university $(43.9 \%)$. The university source with the least reach was reception/open day (19.5\%). Admission interviews (29.3\%) and post graduate fairs $(29.3 \%)$ also ranked low in reaching out to potential students and influencing them to study in the university. 
Table 2b. Personal communication

\begin{tabular}{lllll}
\hline No. & & \multicolumn{4}{c}{ Had Greatest Reach and Influenced Decision to Study at the university } \\
& Personal Communication & A Great Deal or Good Amount & Neutral & A Little or None at All \\
\hline 1. & Friend / Relatives & 56.1 & 24.4 & 19.5 \\
2. & Individuals in professional organisations & 39.1 & 46.3 & 14.6 \\
3. & Peers & 34.1 & 41.5 & 24.4 \\
4. & Mentors & 34.1 & 41.5 & 24.4 \\
5. & Current employer/Supervisor & 34.1 & 36.6 & 29.3 \\
6. & School /career counselor & 26.8 & 43.9 & 29.3 \\
7. & Former employer/supervisor & 22.0 & 48.7 & 29.3 \\
\hline
\end{tabular}

Table $2 \mathrm{~b}$ presents personal sources of communication that had reached and influence on the students' decision to study in the university. Friends and relatives with a percentage of $56.1 \%$ was ranked number one. This was followed by individuals in professional organizations $(39.0 \%)$, peers $(34.1 \%)$, mentors $(34.1 \%)$, current supervisors $(34.1 \%)$, school or career counselor $(26.8 \%)$ with former employer or supervisor $(22.0 \%)$ having the least influence.

Table 2c. Media communication

\begin{tabular}{lllll}
\hline \multirow{2}{*}{ No. } & & \multicolumn{3}{l}{ Had Greatest Reach and Influenced Decision to Study at the University } \\
& Media Communication & A Great Deal or Good Amount & Neutral & A Little or None at All \\
\hline 1. & Published Rankings & 63.4 & 14.6 & 22.0 \\
2. & Post Grad Related Web Sites & 48.8 & 34.1 & 17.1 \\
3. & Media Coverage & 36.6 & 39.0 & 24.4 \\
4. & Online Business Magazines & 29.3 & 39.0 & 31.7 \\
5. & Post Grad Related Books/Publications & 29.3 & 39.0 & 31.7 \\
6. & Chat Room Discussions/ Threaded Discussions & 17.1 & 31.7 & 51.2 \\
\hline
\end{tabular}

Table $2 \mathrm{c}$ presents the media communication source ranked in order of reach and influence. Published ranking with $63.4 \%$ topped the list. This was followed by post graduate related Web sites $(48.8 \%)$, media coverage (36.6\%), post graduate related books / publication $(29.3 \%)$. Chat room discussions / threaded discussion $(17.1 \%)$ had the least reach and influence among media communication sources.

Table 3. Comparison of the reach and influence of the three communication sources

\begin{tabular}{llll}
\hline Source Category & Communication Source & Percentage & Rank \\
\hline University Sources & University Web Site & 87.8 & 1 \\
Media & Published Rankings & 63.4 & 2 \\
Sources & Friend / Relatives & 56.1 & 3 \\
Personal Source & Current students & 51.2 & 4 \\
University & & & 5 \\
Sources & Interaction with admission//post graduate programme personnel & 48.8 & \\
University Sources & & 6 \\
Media & Post Grad Related Web Sites & 48.8 & 7 \\
Sources & Previous experience with university & 46.3 & 8 \\
University Sources & University Alumni & 43.9 & 9 \\
University Sources & Personal correspondence with university & 43.9 & 10 \\
Personal Sources & Individuals in professional organisations & 39.1 & \\
\hline
\end{tabular}


Table 3 presents the ranking of the three communication sources with respect to reach and influence on students' decision to study in the university. The university web site was ranked number one indicating greatest reach and influence. Published ranking from media sources was ranked second while friends/ relatives from personal sources were ranked third. Six of the top ten communication sources which had the greatest reach and influence on potential students were from the university sources.

\subsection{Familiarity with the University Brand}

Table 4. Familiarity with the university brand

\begin{tabular}{|c|c|c|c|c|}
\hline \multirow[b]{2}{*}{ No. } & \multirow[b]{2}{*}{ Brand Familiarity } & \multicolumn{3}{|l|}{ Extent of Agreement } \\
\hline & & $\begin{array}{l}\text { Strongly Agree or } \\
\text { Agree }\end{array}$ & Neutral & $\begin{array}{l}\text { Disagree or Strongly } \\
\text { Disagree }\end{array}$ \\
\hline 1. & I am familiar with the university brand & 85.3 & 9.8 & 4.9 \\
\hline 2. & $\begin{array}{l}\text { I know that this university is the corporate university of the National } \\
\text { Telecommunication Company }\end{array}$ & 80.5 & 12.2 & 7.3 \\
\hline 3. & $\begin{array}{l}\text { I know that this university is the only Malaysian private university in the } \\
\text { Asian top } 200 \text { list. }\end{array}$ & 73.1 & 17.1 & 9.8 \\
\hline 4. & This university is highly recognized & 65.9 & 34.1 & 0 \\
\hline 5. & I know a lot about the university's academic programmes. & 63.4 & 24.4 & 12.2 \\
\hline 6. & $\begin{array}{l}\text { When I hear the name of this university, I immediately recall a particular } \\
\text { academic programme. }\end{array}$ & 58.5 & 29.3 & 12.2 \\
\hline 7. & I often see the university's advertisements in the media & 41.5 & 35.7 & 26.8 \\
\hline 8. & I always hear the university's name mentioned in the media & 31.7 & 39.0 & 29.3 \\
\hline
\end{tabular}

Table 4 presents the familiarity of the respondents with the university brand. A large majority of the respondents $(85.4 \%)$ stated that they were familiar with the university brand. Equally large number (80.5\%) said they knew that university is the corporate university of the government linked national telecommunication company. About $73.1 \%$ knew that university was the only Malaysian private university that had made it into Asia's top 200 lists of universities. About $65.9 \%$ stated that the university is highly recognized; $63.4 \%$ said they knew a lot about the university's academic programmes. Just a little more than half (58.5\%) were able to recall a particular academic programme when they heard the university name. Less than half $(41.5 \%)$ stated that they had often seen university's advertisement in the media and an even smaller percentage (31.7\%) said they always hear the university's name mentioned in the media.

\subsection{Importance of Decision Criteria in Selecting to Study in the University}

Table 5. Importance of decision criteria in choosing to study in the university

\begin{tabular}{|c|c|c|c|c|}
\hline \multirow[b]{2}{*}{ No. } & \multirow[b]{2}{*}{ Decision Criteria } & \multicolumn{2}{|l|}{ Importance of Criteria } & \multirow[b]{2}{*}{$\begin{array}{l}\text { A little or not Important } \\
\text { at All }\end{array}$} \\
\hline & & $\begin{array}{l}\text { Very important or } \\
\text { Important }\end{array}$ & Neutral & \\
\hline 1. & Quality/reputation of the faculty & 90.2 & 9.8 & 0 \\
\hline 2. & Prestige/global recognition of the university & 80.5 & 14.6 & 4.9 \\
\hline 3. & $\begin{array}{l}\text { Published rankings of its graduate } \\
\text { management programme. }\end{array}$ & 75.6 & 19.5 & 4.9 \\
\hline 4. & It is an accredited programme & 73.2 & 24.4 & 2.4 \\
\hline 5. & Local respect & 68.3 & 24.4 & 7.3 \\
\hline 6. & Career options available to graduates & 65.8 & 24.4 & 9.8 \\
\hline 7. & $\begin{array}{l}\text { The students and faculty have diverse } \\
\text { backgrounds and experience }\end{array}$ & 65.8 & 29.3 & 4.9 \\
\hline 8. & $\begin{array}{l}\text { The university's reputation in placing } \\
\text { graduates }\end{array}$ & 63.4 & 29.3 & 7.3 \\
\hline 9. & Location of the university & 61.0 & 19.5 & 19.5 \\
\hline 10. & $\begin{array}{l}\text { The university offered the specific curriculum } \\
\text { I wanted. }\end{array}$ & 53.6 & 36.6 & 9.8 \\
\hline
\end{tabular}


Table 5 presents the importance of decision criteria in choosing to study in the university. Quality/reputation of the faculty ranked top as the most important decision criteria for selecting to study in the university. Others in order of importance were prestige/ global recognition (80.5\%), published rankings of its graduate management programme $(75.6 \%)$, it is an accredited programme $(73.2 \%)$, local respect $(68.3 \%)$, career options available to students $(65.9 \%)$, the students and faculty have diverse backgrounds and experience (65.9\%), the university's reputation in placing candidates $(63.4 \%)$, location of the university $(61.0 \%)$. The university offered the specific curriculum I wanted was ranked last (53.7\%).

\subsection{Importance of Decision Criteria when Choosing Graduate Business School}

Table 6. Importance of decision criteria when choosing graduate business school

\begin{tabular}{|c|c|c|c|c|}
\hline \multirow[b]{2}{*}{ No. } & \multirow[b]{2}{*}{ Decision Criteria } & \multicolumn{2}{|l|}{ Importance of Criteria } & \multirow[b]{2}{*}{$\begin{array}{l}\text { A little or not Important } \\
\text { at All }\end{array}$} \\
\hline & & $\begin{array}{l}\text { Very important or } \\
\text { Important }\end{array}$ & Neutral & \\
\hline 1. & Quality of the faculty & 95.1 & 4.9 & 0 \\
\hline 2. & Local respect / Reputation & 82.9 & 12.2 & 4.9 \\
\hline 3. & Programme type offered & 80.5 & 19.5 & 0 \\
\hline 4. & Rigor of academic programme & 70.7 & 22.0 & 7.3 \\
\hline 5. & Quality of current students & 65.8 & 24.4 & 9.8 \\
\hline 6. & $\begin{array}{l}\text { Published ranking of its graduate } \\
\text { management programme. }\end{array}$ & 78.1 & 19.5 & 2.4 \\
\hline 7. & Job placement reputation of the school & 78.1 & 19.5 & 2.4 \\
\hline 9. & Programme completion time & 70.7 & 19.5 & 9.8 \\
\hline 8. & Successful alumni & 68.3 & 24.4 & 7.3 \\
\hline 11. & Cost of programme & 68.3 & 19.5 & 12.2 \\
\hline 10. & Selectivity of admissions & 39.0 & 53.7 & 7.3 \\
\hline
\end{tabular}

Table 6 presents the decision criteria that prospective post graduate students consider as important when selecting a graduate business school to study. The quality of the faculty $(95.1 \%)$ was ranked number one. Local respect/reputation was ranked second $(82.9 \%)$. Others in descending order of importance are programme type offered $(80.5 \%)$, rigor of the academic programme $(70.7 \%)$, quality of current students $(65.9 \%)$, published ranking of its graduate management programme (78.1), Job placement reputation of the school (78.1\%), programme completion time $(70.7 \%)$, successful alumni $(68.3 \%)$, cost of programme and selectivity of admissions (39.0\%).

Table 7. Nationality of the respondents and reach and influence of communication sources

\begin{tabular}{llrl}
\hline Communication Sources & Mean (Nationality) & Non-Malaysian & $\mathrm{p}$ \\
& Malaysian & N & 3.172 \\
University Sources & 35.10 & 29.90 & $0.003 *$ \\
Personal sources & 23.20 & 19.95 & 1.971 \\
Media Sources & 20.00 & 16.81 & 0.056 \\
\hline
\end{tabular}

Note. $*$ Significant at $\mathrm{p}=0.05$.

An independent $t$ test was used to determine whether there was difference between Malaysian and non-Malaysian students for reach and influence of communication sources. The results are presented in Table 7. There is significance difference between Malaysian and Non-Malaysian students for university sources $(\mathrm{t}=$ $3.172, \mathrm{p}<0.05)$ and media sources $(\mathrm{t}=2.156, \mathrm{p}<0.05)$. These two communication sources had greater reach and influence for Malaysian respondents compared to Non-Malaysian respondents. There was no significant difference between Malaysian and Non-Malaysian respondents for personal sources of communication $(t=1.971$, $\mathrm{p}>0.05$ ). 
4.6 Relationship between Nationality of the Respondents and Familiarity with the University Brand, Decision Criteria in Choosing to Study in the University and for Graduate Business Schools in General

Table 8. Nationality of the respondents and familiarity with the university brand, decision criteria in choosing to study in the university and for graduate business schools in general

\begin{tabular}{|c|c|c|c|c|}
\hline \multirow{2}{*}{ Variables } & \multicolumn{2}{|c|}{ Mean (Nationality) } & \multirow{2}{*}{$\mathrm{t}$} & \multirow{2}{*}{$\mathrm{p}$} \\
\hline & Malaysian & Non-Malaysian & & \\
\hline $\begin{array}{l}\text { Familiarity with the University } \\
\text { Brand }\end{array}$ & 32.15 & 27.14 & 3.242 & $0.002 *$ \\
\hline $\begin{array}{l}\text { Decision Criteria for choosing to } \\
\text { study in the University }\end{array}$ & 28.10 & 24.52 & 3.624 & $0.001 *$ \\
\hline $\begin{array}{l}\text { Decision Criteria for Choosing } \\
\text { Graduate Business School }\end{array}$ & 45.25 & 40.67 & 3.331 & $0.002 *$ \\
\hline
\end{tabular}

Independent $\mathrm{t}$ tests were used to determine whether Malaysian and non-Malaysian students differed with respect to familiarity with the university brand, importance they place on decision criteria for choosing to study in the university and for selecting a graduate business school. There is significant difference between Malaysian and non-Malaysian respondents regarding familiarity with the university brand $(t=3.242, p<0.05)$, importance of decision criteria in choosing to study in the university $(\mathrm{t}=3.624, \mathrm{p}<0.05)$ and in the importance of decision criteria in selecting graduate business school $(\mathrm{t}=3.331, \mathrm{p}<0.05)$ (table 8). Malaysian respondents were more familiar with the university brand (mean $=32.15)$ compared to non-Malaysian respondents $($ mean $=27.14)$. Malaysian place more importance on decision criteria when choosing to study in the university $($ mean $=28.10)$ relative to non-Malaysian students (24.52). Malaysian also place more importance on decision criteria when selecting graduate business schools in general (mean $=45.25)$ compared to non-Malaysians. $($ mean $=40.67)$

\subsection{Relationship between Communication Sources and Familiarity with the University Brand}

Pearson product moment correlation was carried out between the reach and influence of the three communication sources namely university sources, personal sources and media sources. The results are presented in Table 9.

Table 9. Communication sources and familiarity with the university brand

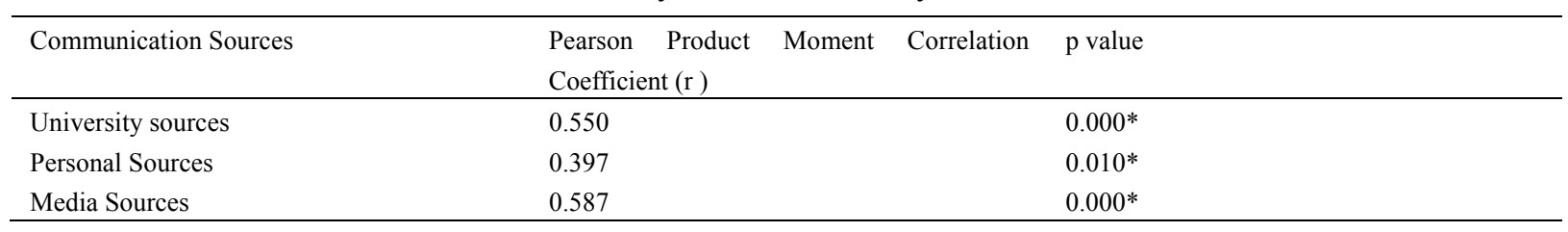

Note. Significant at $\mathrm{p}=0.05$.

The result indicate that there is significant correlation between familiarity of the university brand with university sources $(r=0.550, p<0.05)$, personal sources $(r=0.3970, p<0.05)$ and media sources $(r=0.587, p<0.05)$ (table 9).

4.8 Relationship between Familiarity with the University Brand and Decision Criteria for Selecting to Study in the University

Table 10. Familiarity with the university brand and decision criteria in selecting to study in the university

\begin{tabular}{lll}
\hline & $\begin{array}{l}\text { Pearson Product } \\
\text { Coefficient }(\mathrm{r})\end{array}$ & Moment Correlation \\
\hline Familiarity with the University Brand & 0.557 & $0.000^{*}$ \\
\hline Note. Significant at $\mathrm{p}=0.05$. & &
\end{tabular}

There is significant relationship between familiarity with the University brand and importance of decision 
criteria in choosing to study in the University.

4.9 Relationship between Decision Criteria for Selecting Graduate Business School and Decision Criteria in Selecting to Study in the University

Table 11. Decision criteria in selecting graduate business school and decision criteria in selecting the university

\begin{tabular}{|c|c|c|c|c|}
\hline & $\begin{array}{l}\text { Pearson Product } \\
\text { Coefficient (r) }\end{array}$ & Moment & Correlation & $\mathrm{p}$ value \\
\hline Familiarity with the University Brand & 0.521 & & & $0.000 *$ \\
\hline
\end{tabular}

There seems to be a significant relationship between importance placed on the decision criteria for selecting graduate business school and importance placed on decision criteria in choosing to study in the University (table 11).

\section{Discussion and Conclusion}

University Web site was found to have the greatest reach and influence on students' decision to study in the university. This was published ranking was second and friends /family was third. Of the top ten sources having the greatest reach and influence, six were university sources. This is similar to the results of the Global MBA study (2005) which found that university sources to be the most effective in reach and influence. The remaining are sources from personal or media sources. This is consistent with the findings of Schoenfeld \& Bruce (2005).

Quality / reputation of the faculty topped the list on important decision criteria for selecting to study in the university. This was followed by prestige / global recognition of the university and published ranking of its graduate management programme and that it was an accredited program. This is similar to the research findings of Heslop and Nadeau (2010), who found that reputation and quality of both the faculty and university to be important decision considerations. A similar finding was obtained in the 2002-2004 Global MBA® Graduate Survey. Accredited programme, quality and reputation of the faculty, global recognition and prestige of the school were among the top reasons given by graduating MBA students for selecting the school.

This study found that students placed great importance on quality of the faculty, local respect and reputation of the school and programme type offered. This finding concurs with that of the mba.com Registrants survey conducted in October 2004 in USA.

The study also found that there was significant relationship between university sources and personal sources as communication sources and familiarity with the university brand, familiarity with the university brands and decision to study in the university. In addition there was significant relationship between selecting business school and selecting the university. An important finding especially in relation to attracting international students, the study found that all the communication sources used by the university were significantly more effective for Malaysia students compared to international students.

\section{Recommendation}

The findings of this study has implication for the way higher education and more specifically the MBA program should be marketed by the university. Since university sources and more specifically the university website was found to be the most effective communication source, universities should increase their effort and initiatives to improve these sources especially the university web sites and personal communication from schools so that they are always current, updated and informative. The university should highlight the quality and reputation of the faculty, global recognition as in ranking and global accreditation of the program in their communication sources as these will further serve as a pull factor in attracting students to the MBA program. These will also add to the brand image of the program as this was found to be an important factor in students' selection of the school and university. The university should attract the best people in the academia to be part of its faculty.

Since the number of international students in a university program contributes both its sustainability and the university ranking, it is important to ensure that the communication sources used by the university has international reach. Universities could work with education counselors attached to the foreign embassies to determine the best communication source to the students from their respective countries. Marketing messages should include cross-cultural experiences, opportunity for networking with international students as an added value for studying in the business school of the university. 


\section{Limitations of the Study and Suggestions for Further Research}

This study is a case study of a university. It is an applied research aimed at addressing the problem of declining student enrollment for the MBA program. So the findings are only generalisable to the university that was studied. The sample size was small as it was the total number of students who were enrolled in the first semester of the MBA program. Further research should be carried out with larger samples drawn from a larger population from more Malaysian universities. This will enable the findings to be genralisable over a larger population. A mixed method could be used with in depth interviews conducted with a selected number of students. This will enable a better understanding of the factors that influence students' choice of business school and university for their post graduate education.

\section{References}

Briggs, L. P. (2013). Factors Prospective Students Consider When Selecting an MBA Program. Graduate School Theses and Dissertations. Retrieved from http://scholarcommons.usf.edu/etd/4446

Carrel, A. E., \& Schoenbachler, D. D. (2001). Marketing Executive MBA programs: A comparison of student and sponsoring organization decision considerations. Journal of Marketing for Higher Education, 11(1), 21-38. http://dx.doi.org/10.1300/J050v11n01_02

Dailey, L., Anderson, M., Ingenito, C., Duffy, D., Krimm, P., \& Thomson, S. (2006). Understanding MBA consumer needs and the development of marketing strategy. Journal of Marketing for Higher Education, 16(1), 143. http://dx.doi.org/10.1300/J050v16n01_07158

Graduate Management Admissions Council. (2012). Early Release Edition: 2012 Application Trends Survey, Retrieved from http://www.gmac.com/gmac/researchandtrends/surveyreports/applicationtrendssurvey

Heslop, L. A., \& Nadeau, J. (2010). Branding MBA Programs: The Use of Target Market Desired Outcomes for Effective Brand Positioning. Journal of Marketing for Higher Education, 20(1), 85-117. http://dx.doi.org/10.1080/08841241003788110

Mark, D. R., Daniel, M. S., \& Lusk, J. L. (2002). Comparing Agricultural Economics Graduate Programs: What Are Prospective Students Options? (Rep. No. 179). Lincoln: University of Nebraska, Institute of Agriculture and Natural Resources.

Nicholls, J., Harris, J., Morgan, E., Clarke, K., \& Sims, D. (2011). Marketing higher education: the MBA experience. International Journal of Educational Management, 519(2), 31-38. http://dx.doi.org/10.1108/09513549510082369

Schoenfeld, G., \& Bruce, G. (2005). School Brand Images and Brand Choices in MBA Programs. GMAC Research Reports.

\section{Copyrights}

Copyright for this article is retained by the author(s), with first publication rights granted to the journal.

This is an open-access article distributed under the terms and conditions of the Creative Commons Attribution license (http://creativecommons.org/licenses/by/3.0/). 